\title{
硫化銅鉱の水素による部分脱硫および光の塩酸 浸出に関する研究*
}

芝 山 良 $二^{1}$
田 中 時 昭

1. 緒

$\overline{\overline{⿳ 亠 二 口}}$

銅製鍊に使用されている硫化銅精鉱の主要構成鉱物は Chal copyr i te $\left(\mathrm{CuFeS}_{2}\right)$ である。 $\mathrm{CuFe} \mathrm{S}_{2}$ を主体とす る精鉣である限り， $35 \%$ 以上の銅品位を期待することは難 しい。Fig. 1-a に示した $\mathrm{Cu}-\mathrm{Fe}-\mathrm{S}$ 系三元状態図によれ ば, $\mathrm{CuFeS}_{2}$ を熱分解あるいは水素還元等の方法で脱硫す るとそれぞれ非化学量論組成を有する borni te と pyrrhot i te $(\mathrm{FeS})$ の二相に分離する。 FeS を固溶し広い組成領 域をもつ borni te 相も冷却すると $\mathrm{FeS}$ 相を析出し銅の濃 縮が起こる (Fig. 1-b 参照)。 $\mathrm{Cu}_{5} \mathrm{Fe}_{5}-\mathrm{x} \mathrm{S}_{8-\mathrm{x}}{ }^{2)}$ で表わさ れる borni te 相は天然には $\mathrm{Cu}_{5} \mathrm{FeS}_{4}(\mathrm{x}=4)$ の組成で安 定に存在するが， $\mathrm{Cu}_{2} \mathrm{~S}-\mathrm{Fe} \mathrm{S}$ 線上では $\mathrm{Cu}_{4} \mathrm{FeS}_{3}$ の組成と なることがわかる。

$\mathrm{Cu}_{4} \mathrm{FeS}_{3}$ は銅濃度 62.6 \%となるから，これを $\mathrm{FeS}$ と分
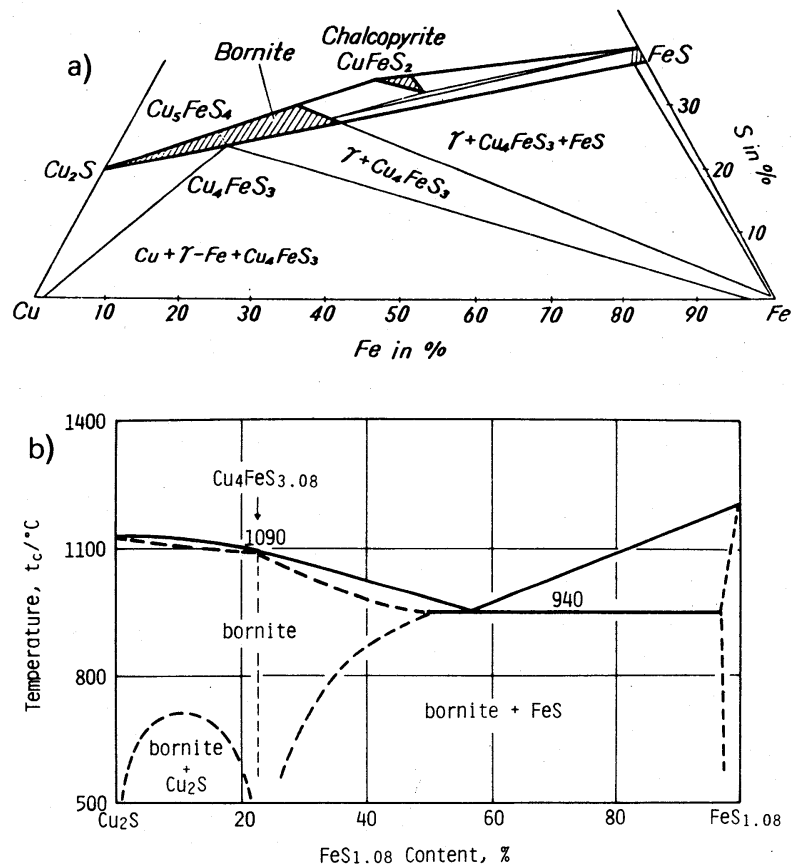

Fig. 1 Schematic phase diagram for $\mathrm{Cu}-\mathrm{Fe}-\mathrm{S}$ system (From Schlegel and Schüller ${ }^{1}$ ))

a: $900^{\circ} \mathrm{C}$ isothermal section

b: the $\mathrm{Cu}_{2} \mathrm{~S}-\mathrm{FeS}_{1.08}$ pseudo-binary diagram

\footnotetext{
* 1982 年 11 月 29 日受理 昭和 56 年日本鉱業会秋季大会分科研究会 で一部発表

1. 正会員 北海道大学助手 工学部金属工学科

2. 正会員 工博 北海道大学教授 工学部金属工学科
}

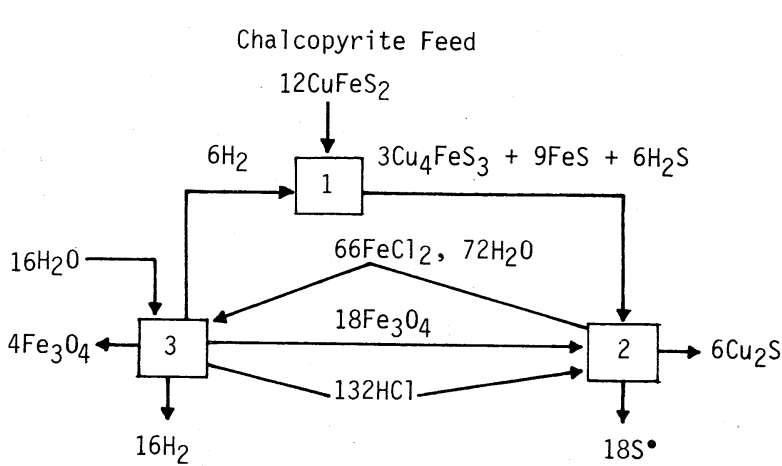

1. $12 \mathrm{CuFeS}_{2}+6 \mathrm{H}_{2} \rightarrow 3 \mathrm{Cu}_{4} \mathrm{FeS}_{3}+9 \mathrm{FeS}+6 \mathrm{H}_{2} \mathrm{~S}$

2. $3 \mathrm{Cu}_{4} \mathrm{FeS}_{3}+9 \mathrm{FeS}+18 \mathrm{Fe}_{3} \mathrm{O}_{4}+132 \mathrm{HCl}+6 \mathrm{H}_{2} \mathrm{~S}$

$\rightarrow 66 \mathrm{FeCl}_{2}+6 \mathrm{Cu}_{2} \mathrm{~S}+18 \mathrm{~S}^{\bullet}+72 \mathrm{H}_{2} \mathrm{O}$

3. $66 \mathrm{FeCl}_{2}+88 \mathrm{H}_{2} \mathrm{O} \rightarrow 22 \mathrm{Fe}_{3} \mathrm{O}_{4}+132 \mathrm{HCl}+22 \mathrm{H}_{2}$

Fig. 2 Process scheme for the pretreatment of copper concentrates by hydrogen.

離し得るならば, 銅精鉱の品位向上のほか従来 slag とし て廃棄されていた鉄分の回収, さらには硫黄についても元 素硫黄としての回収ができ硫酸の過剩生産に対し桑軟性を 保てる。このためFig. 2 に示すフローシートによる処理法 を提案し, 各構成反応について研究を行なつた。反応 3 に

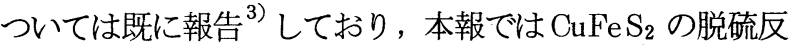
応および脱硫産物の塩酸浸出結果について述べる。

\section{2. 実験 方 法}

\section{$2 \cdot 1$ 実験試料}

実験に供した硫化銅鉣はPecco鉱山産の銅精鉱と秋田県 宮田又鈗山産の chal copyr i te 結晶を- 70 +200 mesh に粉研した 2 種である。精鉱の分析值をTable 1 に掲げた。 X線回折より構成鉱物として chal copyri te, pyri te $\left(\mathrm{FeS}_{2}\right)$ おおよびmagnet i te $\left(\mathrm{Fe}_{3} \mathrm{O}_{4}\right)$ が同定された。また顕 微鏡観察から上記鉱物以外に cove l i te ( CuS ) も認められ

Table 1 The analysis of chalcopyrite concentrates.

\begin{tabular}{c|c|c|c|c|c|c}
\hline $\mathrm{Cu}$ & $\mathrm{Fe}$ & $\mathrm{S}$ & $\mathrm{Pb}$ & $\mathrm{Zn}$ & $\mathrm{Bi}$ & $\mathrm{Co}$ \\
\hline 22.2 & 28.6 & 39.3 & 1.5 & 0.50 & 0.30 & 0.30 \\
\hline 24.6 & 31.8 & 43.6 & \multicolumn{4}{|c|}{${ }^{*} \mathrm{Cu}+\mathrm{Fe}+\mathrm{S}=100 \%$} \\
\hline $\mathrm{CaO} 0$ & $\mathrm{MgO}$ & $\mathrm{SiO}_{2}$ & \multicolumn{2}{|c|}{$\mathrm{Au}$} & \multicolumn{2}{|c}{$\mathrm{Ag}$} \\
\hline 0.71 & 0.77 & 5.1 & $11.7 \mathrm{~g} / \mathrm{t}$ & \multicolumn{2}{|c}{$107 \mathrm{~g} / \mathrm{t}$} \\
\hline
\end{tabular}

日本鉱業会誌/100 1151 ('84-1) $47<47>$ 
た。一方, 天然産 chal copyr i te 結晶の化学分析は化学量 論值と一致し，X線回折からも純粋な結晶であることが確 められた。

\section{$2 \cdot 2$ 実験方法}

chal copyr i teの熱的挙動を調べる実験は前記の結晶試 料を用い，軷型石英反応管で行なつた。 $\mathrm{Ar}$ および $\mathrm{H}_{2}$ 気流 中での実験ではガス流量 $500 \mathrm{ml} / \mathrm{min}$, 試料量 $100 \mathrm{mg}$ と し, また減圧下の場合は $10^{-2} \sim 10^{-3} \mathrm{mmHg}$ および $500 \mathrm{mg}$ の条件とした。

試料は石英バスケットに入れ，反応管上部に取りつけた 巻き上げ用コックで反応管上部に引上げておき，炬が所定 温度に達した後, 降下させ反応時間経過後, 再び反応管上 部に引上げ急冷させた。次いで反応前後の重量変化を測定 するとともにX線回折および検鏡用の試料とした。

塩酸浸出実験用の試料は銅精鉱については $6 \mathrm{~g}$, chalcopyri te では $4 \mathrm{~g}$ をそれぞれ， $\mathrm{H}_{2}$ 流量 $100 \mathrm{ml} / \mathrm{minで}$ 還元 したもので塩酸浸出時には, 銅精鉱の場合は $4 \mathrm{~g}, \mathrm{chalco}^{-}$ pyrite については $2.5 \mathrm{~g}$ を試料量とし, 液量 $200 \mathrm{ml}$ 中 で浸出し, 反応時間終了後直ちにガラスフィルタで濾過乾 燥した。浸出中の攪拌は 2 分毎に 1 回浸出液を軽く振り動

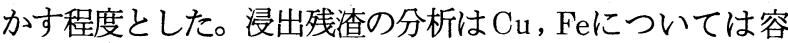
量法，またSについては水素還元による重量法を用いた。 銅精鉱中の $\mathrm{Fe}, \mathrm{Cu}$ および $\mathrm{S}$ 以外の成分については分析を していないため，分析值の合計が $100 \%$ となるように，そ れぞれの分析值を比例配分して補正した。

borni te の塩酸浸出挙動を調べるために使用した borni teは, まず $\mathrm{Cu}_{2} \mathrm{~S}, \mathrm{CuS}$ および $\mathrm{FeS}$ をそれぞれ真空アンプ ル中で金属と結晶硫黄から合成し，その後これら各硫化物 を所定の組成比となるよう科量混合し，真空アンプル中で 再合成した。

\section{3. 実 験 結 果}

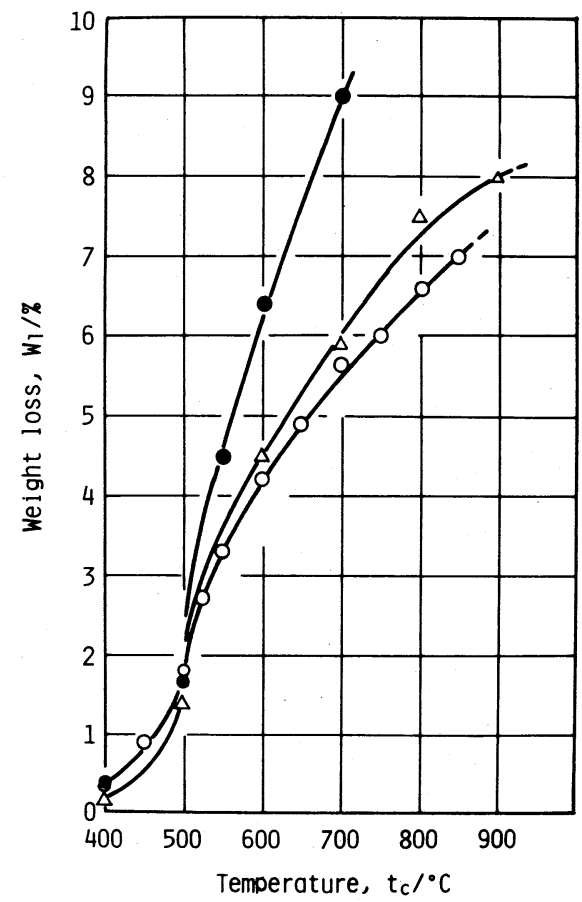

- $\mathrm{H}_{2}, 15 \mathrm{~min}$ $\triangle$ Vacuum, $1 \mathrm{~h}$

O $\mathrm{Ar}, 4 \mathrm{~h}$ emperature an atmosphere on the desulfuriza tion of
chalcopyrite.

\section{$3 \cdot 1$ 脱硫曲線と固体生成物}

Fig. 3 に各種雾囲気下における $\mathrm{CuFe} \mathrm{S}_{2}$ の脱硫時に得ら れた重量減少曲線を示した。また Table 2 に各温度におけ る固体生成物のX線回折による同定結果も併せて示した。 Table 2 によれば $\mathrm{CuFeS} \mathrm{S}_{2}$ の脱硫は次の各段階を経て進む ことがわかる。

step $1 \quad \mathrm{CuFeS}_{2} \rightarrow \mathrm{Cu}_{1+x} \mathrm{Fe}_{1+x} \mathrm{~S}_{2}$

step $2 \quad \mathrm{Cu}_{1+\mathrm{x}} \mathrm{Fe}_{1+\mathrm{x}} \mathrm{S}_{2} \rightarrow \mathrm{Cu}_{5} \mathrm{Fe}_{5-\mathrm{x}} \mathrm{S}_{8-\mathrm{x}}+\mathrm{Fe}_{1-\mathrm{x}} \mathrm{S}$ また, $\mathrm{H}_{2}$ 気流中ではさらに上記段階に続いて,

step $3 \quad \mathrm{Cu}_{5} \mathrm{Fe}_{5-\mathrm{x}} \mathrm{S}_{8-\mathrm{x}}+\mathrm{Fe}_{1-\mathrm{x}} \mathrm{S} \rightarrow \mathrm{Cu}+\mathrm{Fe}$ の過程が伴い金属相が生成する。なお， $\mathrm{Cu}_{2-\mathrm{x}} \mathrm{S}$ 相が同定 されていないことから，下記のような反応を経由する金属 相の生成は起こらないことがわかる。

$\mathrm{Cu}_{5} \mathrm{Fe}_{5-x} \mathrm{~S}_{8-\mathrm{x}} \rightarrow \mathrm{Cu}_{2-\mathrm{x}} \mathrm{S}+\mathrm{Fe}_{1-\mathrm{x}} \mathrm{S} \rightarrow \mathrm{Cu}+\mathrm{Fe}$

上述の生成物相の変化を Fig. 3の脱硫曲線と対比して考 えると， $500^{\circ}$ C 付近で脱硫率の著しい立上りがみられ，こ れは step 1 に相当する。しかし, step 2 および 3 に対応 する変化は脱硫曲線中には認められない。一方, 示差熱分 析結果によれば $500^{\circ}$ C 付近に明らかに step 1 に相当する 吸熱ピークが得られたが，他の段階に対応したピークは見 出されなかつた。したがつて, step 2 以降の相変化は温 度よりもむしろ脱硫量に強く依存しているといえ，X線回 折結果からも脱硫率が $14 \%$ 以上になると,いずれの雾囲気 でも bornite と pyrrhotiteの二相に分解していることが わかつた。またFig.1ー、から,

$4 \mathrm{CuFe} \mathrm{S}_{2} \rightarrow \mathrm{Cu}_{4} \mathrm{FeS}_{3}+3 \mathrm{FeS}+\mathrm{S}_{2}$ の反応に相当する $25 \%$ 以上の脱硫を受けると金属相の生 成が起こり始めると考えられる。これは $700^{\circ}$ Cの水素還元 時の金属の生成結果ともよく一致する。

\section{$3 \cdot 2$ 脱硫に伴う相変化の観点}

$\mathrm{CuFeS}_{2}$ 粒子の水素還元時の相変化を知るため前述の試 料について粒子断面の光学顕微鏡観察を行ない, 以下の諸 事実を確認した。

step 1 に相当する $\mathrm{Cu}_{1+\mathrm{x}} \mathrm{Fe}_{1+\mathrm{x}} \mathrm{S}_{2}$ ( $\beta$ - chalcopyrite) への変化は粒子表面から内部に向つてトポケミカルに進行 するのではなく，粒子全体が一様に $\beta$ 相に変化する。また， この段階で認められる唯一の変化は粒子全体の色調が赤味 がかる程度であつた。

step 2 の $\beta$ 相から borni te相への移行過程では step 1 と同様にトポケミカル的 bornite相の生成は認められず, 粒子内部に帯状あるいは Photo. 1 に示寸球状の borni te
Table 2 X-ray diffraction analysis of desulfurized chalcopyrite.

\begin{tabular}{ccccccc}
\hline \hline temp. ${ }^{\circ} \mathrm{C}$ & & & & & & \\
\hline atmosphere & 400 & 500 & 600 & 700 & 800 & 900 \\
\hline Ar & $\alpha$ & $\beta$ & $\beta$ & $\beta, b, p$ & $b, p, \beta$ & \\
Vaccum & $\alpha$ & $\beta$ & $\beta$ & $\beta, b, p$ & $b, p, \beta$ & $b, p$ \\
$H_{2}$ & $\alpha$ & $\beta$ & $\beta, b, p$ & $p, b, c, i$ & & \\
\hline
\end{tabular}

a. $\mathrm{CuFeS}_{2}$ B. $\mathrm{Cu}_{1+x} \mathrm{Fe}_{1+x} \mathrm{~S}_{2}$ b. $\mathrm{Cu}_{5} \mathrm{Fe}_{5-x} \mathrm{~S}_{8-x}$

p. $\mathrm{Fe}_{1-x} \mathrm{~S}$ c. $\mathrm{Cu}$ i. $\mathrm{Fe}$ 

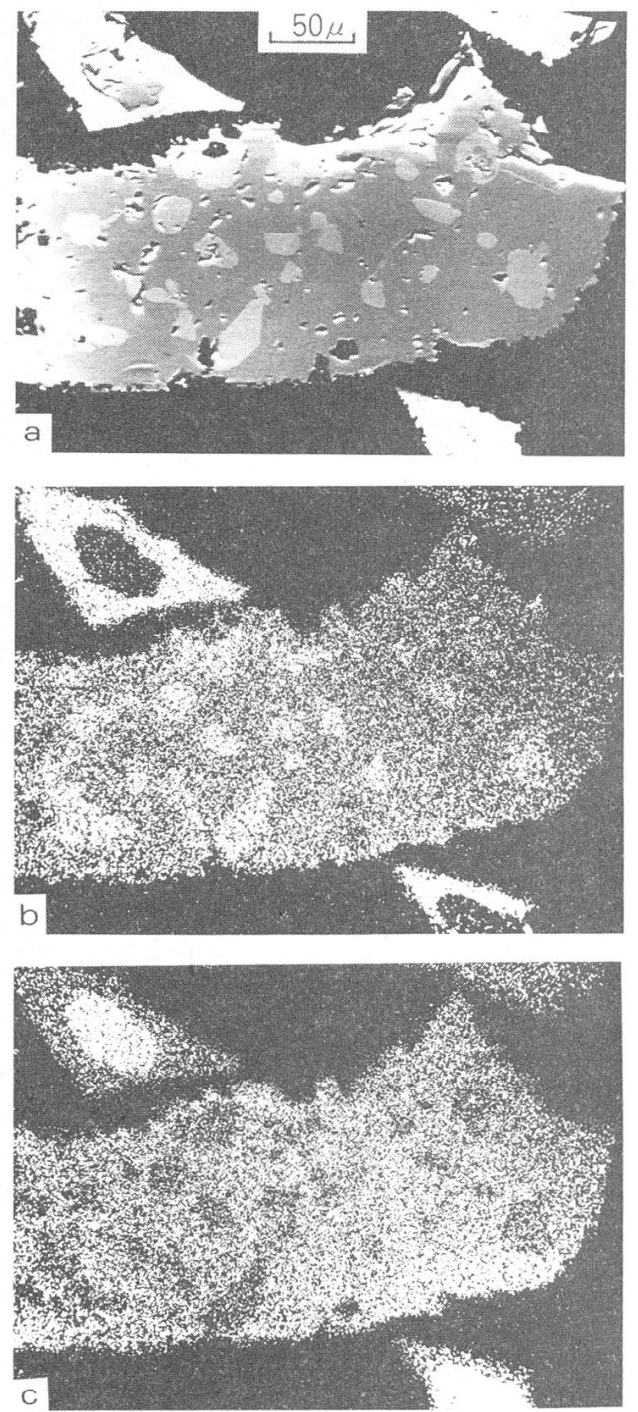

$\leftarrow$ Photo. 1

Electron probe microanalysis showing the precipitation of bornite from $\beta$-chalcopyrite and the formation of pyrrhotite surrounded by bornite.

a: composition image

b: $\mathrm{Cu}-\mathrm{K} \alpha$ image

c: $\mathrm{Fe}-\mathrm{K} \alpha$ image 相が析出してくる。しかし，このようなborniteの析出初 期の段階では FeS 相と明確に同定でさる析出物は認められ なかつた。脱硫が進むにつれ, 析出物の凝集, 成長が起こ り, 逆にbornite マトリックス中に $\beta$ 相が分布する状態と なる。このような状態になるにつれ， $\beta$ 相の色調は次第に 白くなり，明らかに FeS 相として判定できるようになる (Photo.1の左上粒子参照)。

熱分解による脱硫では, Table 2からも明らかなように $\beta$ 相を完全に分解させるために高い温度を必要とする。一 方, 水素還元では強い脱硫力のため, Photo.2にみられる ようにbornite と塊状FeS のほかにbornite 相内にも細 かいラメラー状の析出物を伴う組織が得られた。Fig. 1-b によれば，FeSの borni teに対する溶解度は温度依存性 が著しく大きく, したがつて, 試料冷却時に bornite 相に 溶けこんでいたFeSが析出したものとみられる。

上述のような二相混合物の金属への還元では, 初めに borni te相から繊維状に金属鉄の生長が起こる。これに伴 いbornite相内に塊状に析出していた FeS相はしだいと消 失するとともに，ラメラー状析出物もみられなくなる。こ の間, 金属銅の生成は金属鉄に較べ少ないことがわかつた。 さらに還元が進さと金属銅が bornite相からやはり繊維状

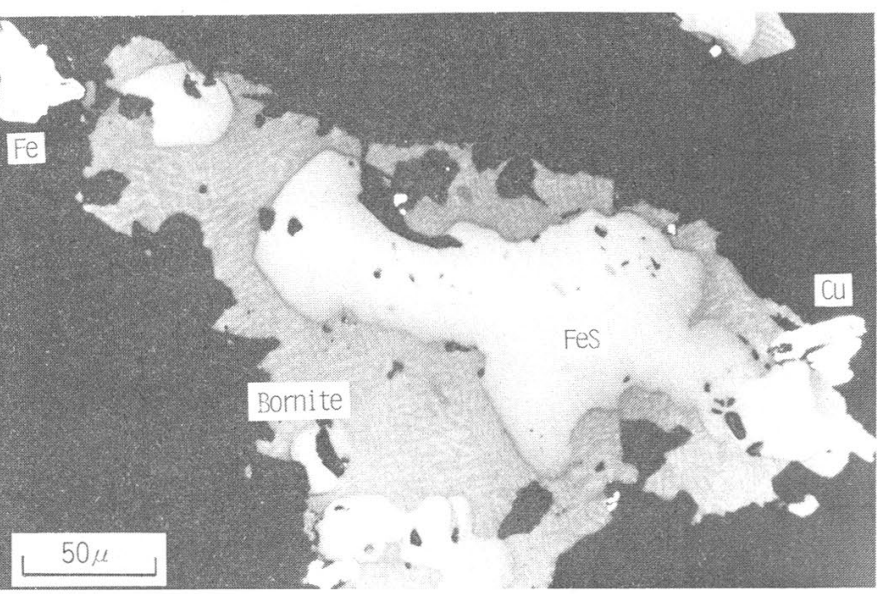

Photo. 2 Photomicrograph of pyrrhotite and bornite resulting from partial reduction of chalcopyrite with hydrogen. The light-colored lamellae in bornite are pyrrhotite exsolving from bornite solid solution.

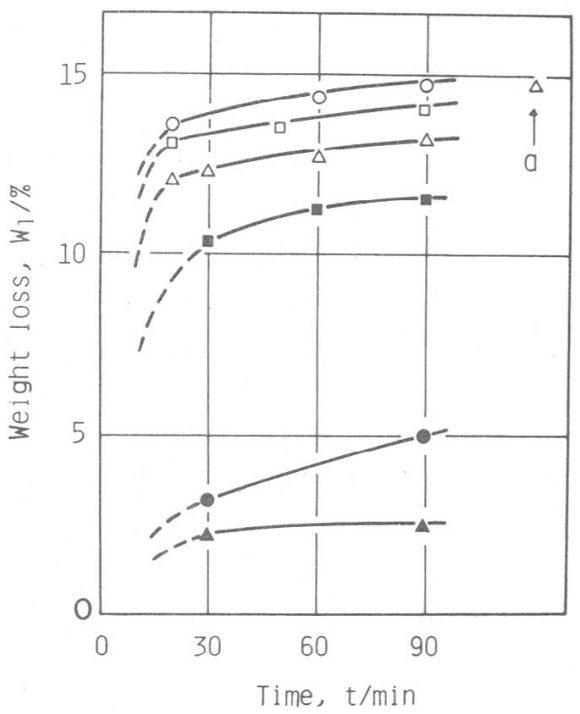

Fig. 4 Reduction of copper concentrates by $\mathrm{H}_{2}$ at different temperatures.

$\circ 800^{\circ} \mathrm{C} \square 700^{\circ} \mathrm{C} \triangle 600^{\circ} \mathrm{C}=500^{\circ} \mathrm{C}-400^{\circ} \mathrm{C}$

$\Delta 300^{\circ} \mathrm{C}$ Letter a indicates $16 \mathrm{~h}$

に生長してくるが，銅と鉄はそれぞれ表面の別々の場所か ら生成してくる。睘元が終了した時点では，繊維状金属が 絡みあつた鳥の宩状となる。

\section{$3 \cdot 3$ 浸出用試料の脱硫試験}

浸出実験用に $6 \mathrm{~g}$ の銅精鉱試料を用い脱硫方法の影響を 調べた。減圧熱分解による脱硫では, 分解ガスや昇華性化 合物のため真空度の低下のほか, 試料の焼結現象もみられ た。精鉱中の $\mathrm{FeS}_{2}$ は $600^{\circ} \mathrm{C}$ 位までで分解され，またより高 い温度では PbSが昇華してくるとともに, 焼結に伴い試料 層内部の脱硫が進みにくくなる。これに対し，水素還元で は焼結よりもむしろ膨張し, 脱硫量も減圧下に較べ 2 倍程 度大きく効果的であることがわかつた。

Fig.4に精鉱の脱硫に及ぼす水素還元時間の影響を示し た。図より明らかなように還元開始 20 分程度までに著し い初期重量減少がみられ，それ以後は還元時間延長の効果 は小さくなる。CuFe $\mathrm{S}_{2}$ はいても同様な実験を行ない精 鉱の場合と類似の曲線を得た。しかし，還元速度の低下が 


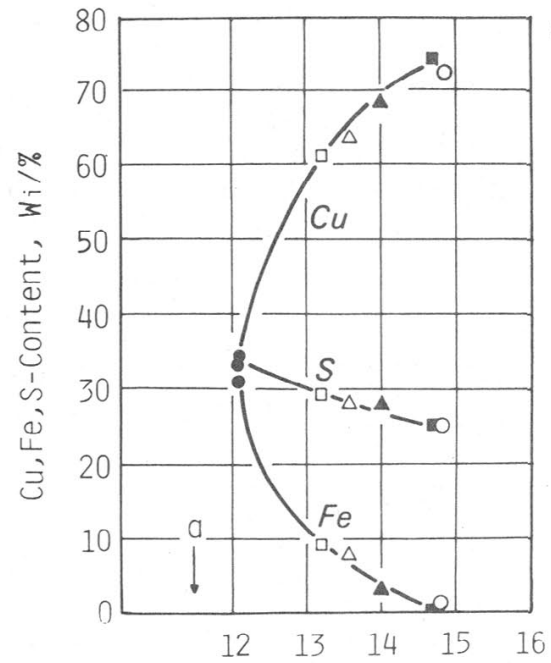

Weight loss, Wi $/ \%$
Fig. 5 Composition of residue obtained when copper concentrates were partially reduced by $\mathrm{H}_{2}$, then leached in $\mathrm{HCl}$ solution for $20 \mathrm{~min}$.

-1 $800^{\circ} \mathrm{C}, 2 \mathrm{~h}, 1: 10 \mathrm{HCl}, 80^{\circ} \mathrm{C}$

$\Delta 700^{\circ} \mathrm{C}, 2 \mathrm{~h}, 1: 10 \mathrm{HCl}, 80^{\circ} \mathrm{C}$

ㅁ $600^{\circ} \mathrm{C}, 2 \mathrm{~h}, 1: 10 \mathrm{HCl}, 80^{\circ} \mathrm{C}$

$600^{\circ} \mathrm{C}, 16 \mathrm{~h}, 1: 2 \mathrm{HCl}, 40^{\circ} \mathrm{C}$

$600^{\circ} \mathrm{C}, 20 \mathrm{~min}, 1: 2 \mathrm{HCl}, 40^{\circ} \mathrm{C}$

$800^{\circ} \mathrm{C}, 20 \mathrm{~min}, 1: 2 \mathrm{HCl}, 40^{\circ} \mathrm{C}$

Position a indicates the dissolution of $\mathrm{Cu}$.

Effect of partial desulfurization of chalcopyrite by $\mathrm{H}_{2}$ on the composition of residue obtained after leaching in $\mathrm{HCl}$ solution. Position a indicates the original composition.

$\circ \mathrm{Cu} \triangle \mathrm{S} \bullet \mathrm{Fe}$

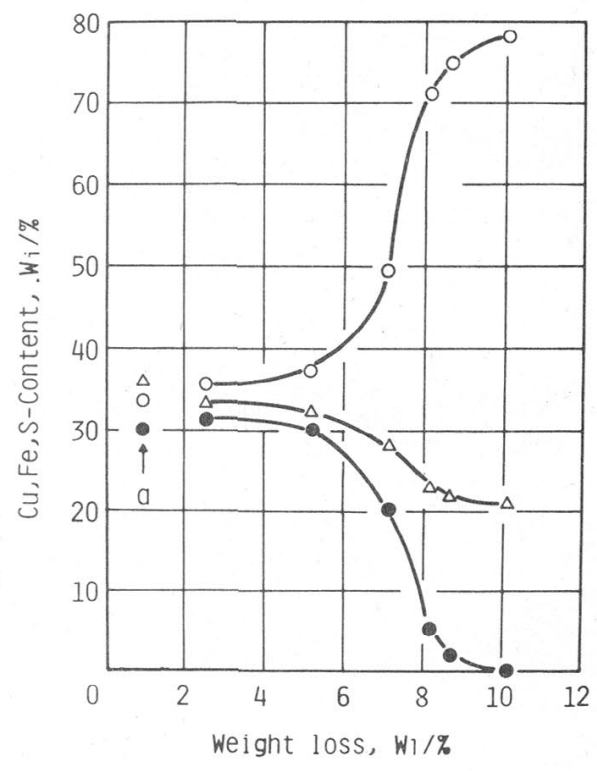

も同様な実験から Fig. 6 の結果を得た。いずれの試料も $\mathrm{H}_{2} \mathrm{~S}$ を発生し銅の溶解はみられなかつた。重量減少率が7 $\%$ 以上になると残渣中の銅濃度の上昇が顕著になり, 浸出 時に激しい $\mathrm{H}_{2} \mathrm{~S}$ の発生を伴い 3 ～ 5 分間で浸出を完了する。 また未還元の $\mathrm{CuFeS}_{2}$ では $\mathrm{H}_{2} \mathrm{~S}$ の発生や銅の溶解は認めら れなかつた。

浸出前の試料が bornite と FeSの二相からなり, FeS 相 の選択溶解が進さとすれば，浸出残渣はbornite 相 のみ からなり, 残渣の銅品位は $\mathrm{Cu}_{4} \mathrm{FeS}_{3}$ の $62.6 \%$ あるいは $\mathrm{Cu}_{5} \mathrm{FeS}_{4}$ としても $63.6 \%$ 程度にしかならないはずである。 しかし，実験結果は 73〜 79\%と $\mathrm{Cu}_{2} \mathrm{~S}$ に近い組成を示す ものもあり, FeS 相の選択溶解だけでは説明できず, bornite 相加らの Feの溶解 ${ }^{6)}$ 考えなければならない。天然に 存在寸る安定な $\mathrm{CuFeS}_{2}$ や $\mathrm{Cu}_{5} \mathrm{FeS}_{4}$ は非酸化性の酸には溶 解しないが, 非化学量論組成を有する場合の溶解挙動につ いては未だ解明されていない。

Photo. 3 にPhoto. 2 に対応する試料の浸出後の顕微鏡 写真を示した。浸出後には FeS 相の空洞化した部分と少量 のbornite しか認められず, bornite相の大部分は $\mathrm{Cu}_{2} \mathrm{~S}$ 相に変化したことがわかる。また $\mathrm{Cu}_{2} \mathrm{~S}$ 部分にみられる空

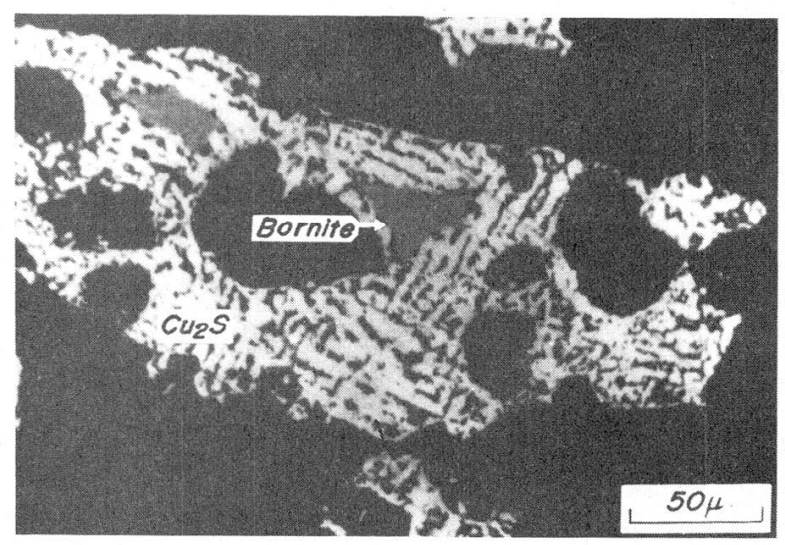

Photo. 3 Photomicrograph of residue obtained after leaching in $\mathrm{HCl}$ solution showing the selective dissolution of FeS and the formation of $\mathrm{Cu}_{2} \mathrm{~S}$.
度までの重量減少は精鉱中の $\mathrm{CuFe}_{2}$ に対してほとんど変 化をもたらしていないといえる。純粋な $\mathrm{CuFeS}_{2}$ について 
隚は浸出前に borni te 相内にみらられたメラー状析出物部 分に対応しているようにみえる。Fig. 7 に精鉱および $\mathrm{CuFeS} \mathrm{S}_{2}$ のそれぞれの浸出残渣組成を $\mathrm{Cu}-\mathrm{Fe}-\mathrm{S}$ 三成分系 図上に示した。両者とも脱硫量の小さい場合を除けば, 特 定の直線上に分布していることがわかる。

\section{5 浸出に及ぼすborniteの非化学量論性の影響} 上述の結果から還元で生成した F e S 相の溶解以外に， borni te相からも FeS としてのFeの溶解反応が進行し， さらにこの FeS としての溶解量は水素還元時の bornite の脱硫量によつて決まることを意味している。このため脱 硫量の違いによる浸出残渣のX線回折図形の変化を調べて みた。銅精鉱を $600^{\circ} \mathrm{C} て ゙ 2$ 時間拉よび 16 時間水素還元し， 重量減少率がそれぞれ $13 \%$ おび $14.9 \%$ の試料の浸出前 後の变化をFig. 8 に示した。図にはbornite の最強回折 線 (088) 付近を揭げたが, 浸出前はいずれも FeS と borni te.回折線のみからなり, 16 時間還元した試料の borniteの格子定数がやや大きくなつている程度の差しか認め られない。しかし, 浸出残渣の比較では 16 時間還元 試料 では borniteの回折線が消失し, $\mathrm{Cu}_{2} \mathrm{~S}$ の最強回折線が現 われる。一方, 2 時間の試料では $\mathrm{Cu}_{2} \mathrm{~S}$ の回折線とともに bornite の回折線も依然として認められ,かつ格子定数は 浸出前より縮小していることがわかる。

このように borniteの組成の影響が重要視されたため, 合成 borniteを用いてその単独の場合の溶解挙動を調べて みた。合成borniteとしては次の3 種類の組成について実 験した。

No. $1 \mathrm{Cu}_{5} \mathrm{FeS}_{4}\left(\mathrm{CuS}+2 \mathrm{Cu}_{2} \mathrm{~S}+\mathrm{FeS}\right)$

No. $2 \mathrm{Cu}_{4.5} \mathrm{FeS}_{3.5}\left(0.5 \mathrm{CuS}+2 \mathrm{Cu}_{2} \mathrm{~S}+\mathrm{FeS}\right)$

No. $3 \quad \mathrm{Cu}_{4} \mathrm{FeS}_{3}\left(2 \mathrm{Cu}_{2} \mathrm{~S}+\mathrm{FeS}\right)$

括弧内は合成の際に用いた各硫化物の混合比率を示す。浸 出条件は 1: 2 塩酸溶液を用い, 温度 $40^{\circ} \mathrm{C}$, 浸出時間 20 分および240 分とした。結果をTable 3 に掲げた。

No. 1 の試料 ( 天然産 borni te の組成と同じ) では $\mathrm{H}_{2} \mathrm{~S}$ の発生は認められず, 時間の経過とともにCuの溶出がみ られた。しかし, 溶解速度は極めて遅く, 空气酸化による ものとみなされる。一方，No. 2 およびNo.3の試料ではい

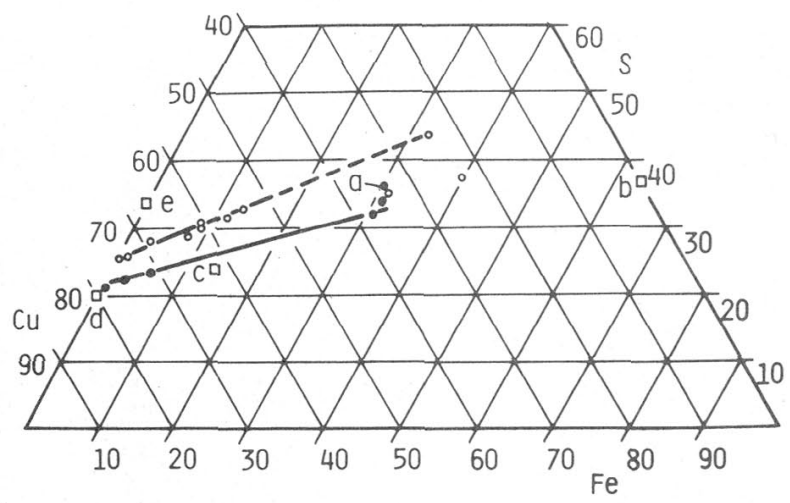

Fig. 7 The composition of related minerals and of the residue obtained after leaching of partially reduced product.

- copper concentrates chalcopyrite

a. $\mathrm{CuFeS}_{2} ;$ b. FeS; c. $\mathrm{Cu}_{4} \mathrm{FeS}_{3}$; d. $\mathrm{Cu}_{2} \mathrm{~S}$; e. $\mathrm{CuS}$

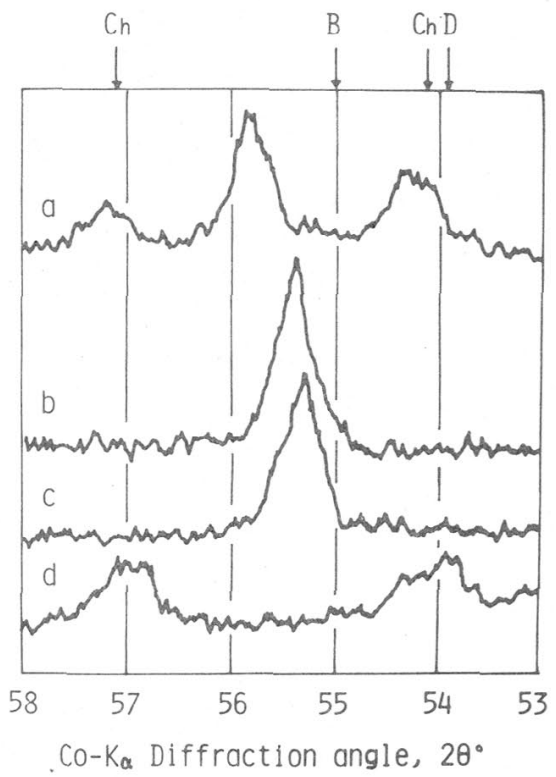

Fig. 8 X-ray patterns showing the mineralogical transformation of bornite obtained before and after leaching.

a. Residue after leaching of $b$;

b. Reduced at $600^{\circ} \mathrm{C}$ for $2 \mathrm{~h}$;

c. Reduced at $600^{\circ} \mathrm{C}$ for $16 \mathrm{~h}$;

d. Residue after leaching of $\mathrm{c}$;

Ch. Chalcocite, $1.870 \AA, 1.967 \AA$;

B. Bornite, $1.937 \AA$;

D. Digenite, $1.973 \AA$

Table 3 Dissolution of Fe from the synthetic bornite in $1: 2 \mathrm{HCl}$ at $40^{\circ} \mathrm{C}$.

\begin{tabular}{llll}
\hline & & \multicolumn{2}{c}{ leaching time (min) } \\
\cline { 3 - 4 } No. composition & \multicolumn{1}{c}{20} & 240 \\
\hline 1 & Cu$_{5} \mathrm{FeS}_{4}$ & $n i 1$ & $n i 1$ \\
2 & $\mathrm{Cu}_{4} .5 \mathrm{FeS}_{3} .5$ & $33.9 \%$ & $51.2 \%$ \\
3 & $\mathrm{Cu}_{4} \mathrm{FeS}_{3}$ & 49.3 & 68.6 \\
\hline
\end{tabular}

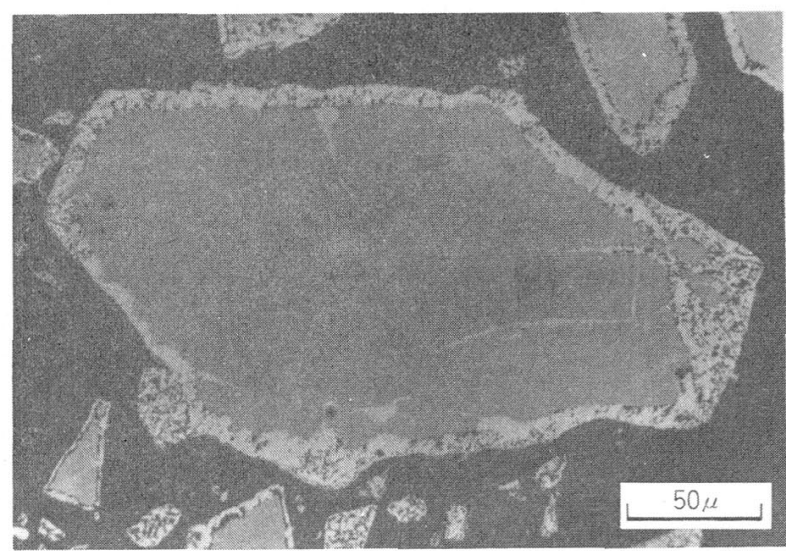

Photo. 4 Photomicrograph of $\mathrm{Cu}_{4} \mathrm{FeS}_{3}$ after leaching in 1:2 $\mathrm{HC} 1$ at $40^{\circ} \mathrm{C}$ for $30 \mathrm{~min}$ showing the formation of $\mathrm{Cu}_{2} \mathrm{~S}$.

ずれも浸出直後から $\mathrm{H}_{2} \mathrm{~S}$ の発生を伴い Feの溶出が起こる。 表から $\mathrm{Fe}$ の溶出量は $\mathrm{Cu}_{5} \mathrm{FeS}_{4}$ の組成からの偏倚が大きい ほど大きくなることが明らかである。No.2 の試料は 240 分後には $\mathrm{H}_{2} \mathrm{~S}$ の発生が止り, $\mathrm{Cu}$ の溶出が認められた。 $\mathrm{X}$ 線回折からNo. 2 おうよびNo. 3 では $\mathrm{Cu}_{2} \mathrm{~S}$ 相が同定された。

Photo. 4 にNo. 3 の浸出時の顕微鏡写真を示した。粒子 周辺部の $\mathrm{Cu}_{2} \mathrm{~S}$ 化の様子は水素還元試料の場合と大差はな 
いが，粒子の内部にも明らかに $\mathrm{Cu}_{2} \mathrm{~S}$ の析出が認められる。 これは粒子の割目からの浸出液の侵入とはみられず, 浸出 に伴い粒子内で金属イオンの拡散が起こり, 析出したもの と考えられる。bornite 相の金属イオンの移動が容易なこ とは水素還元時に繊維状金属生長が起こることからも推定 できる。

\section{4. 結論}

部分脱硫による銅精鉱の浸出活性化, 脱硫産物の塩酸浸 出による鉄の選択的溶解と銅の同時濃縮について基礎的実 験を行ない次の諸結果を得た。

$\mathrm{CuFeS}_{2}$ の脱硫により生成固相は次のように変化するこ とが明らかにされた。

$$
\begin{aligned}
& \mathrm{CuFeS}_{2} \rightarrow \beta-\text { chal copyrite } \rightarrow \text { bornite }+\mathrm{Fe}_{1-x} \mathrm{~S} \\
& \quad \rightarrow \mathrm{Fe}+\text { bornite } \rightarrow \mathrm{Fe}+\mathrm{Cu}
\end{aligned}
$$

さらに, 水素還元では生成FeS は bornite相に取囲まれ 塊状化し, 金属はbornite 相加ら生成する。金属鉄は繊維 状に成長し，これに伴いFeSは次第に消失する。その後金 属銅も繊維状成長することがわかつた。

水素による脱硫法は他の不活性ガスおよび減圧等による 方法に較べ, 反応速度ならびに bornite と FeS の二相へ の分解および両者の分離状態の観点から非常に効果的であ ることが確められた。
浸出残渣中の銅濃度の上昇は $\mathrm{CuFeS}_{2}$ の場合, 重量減少 率 $7 \%$ 以上から影著になること，残渣の銅濃度は部分脱硫 量のみに依存し, 浸出条件にはほとんど影響を受けないこ とが確認された。

浸出反応は $\mathrm{H}_{2} \mathrm{~S}$ の発生を伴つて進み, FeS 相の溶解の みならずborniteからも Feの選択的溶出が起こる。borniteからの Feの溶出量はその非化学量論組成に強く依存 する。Feの溶出に伴い borni te は $\mathrm{Cu}_{2} \mathrm{~S}$ 相に変化する。 このため最適部分脱硫条件では鉄分をほとんど含まず，か 銅濃度も 70 数\%に達する硫化銅残渣が得られことが確 められた。

$$
\text { 参考文献 }
$$

1) Schlegel, II. \& Schiiller, A. : Z. Metallkunde, 43, $421 \sim 428$, (1952)

2) Gabler, R. C., et al. : U. S. Bur. Mines Rept. Invet., 8067, (1975)

3）芝山良二.中島和夫 ·土田直行 - 由中時昭：日本鉱業会誌，97, $41 \sim 47, \quad(1981)$

4) Subramanian, K. N. \& Jennings, P. H. : Can. Met. Quarterly, 11, 387 400, (1972)

5) Ingraham, T.R., Parsons, H. W. \& Cabri, L. J. : Can. Met. Quarterly, 11, 407 411, (1972)

6) Habashi, F. : Chalcopyrite-Its Chemistry and Metallurgy-, 116, (1978), McGraw-Hill Inc. (New York )

\title{
Partial Desulfurization of Copper Concentrates with Hydrogen and Copper Enrichment by Hydrochloric Acid Leaching
}

\author{
by Ryoji SHIBAYAMA ${ }^{1}$ and Tokiaki TANAKA ${ }^{2}$
}

The activated leaching of chalcopyrite with hydrogen was investigated in this paper for the up-grading of copper concentrates and the recovery of $\mathrm{S}$ as $\mathrm{S}^{\circ}$ and of $\mathrm{Fe}$ as $\mathrm{Fe}_{3} \mathrm{O}_{4}$. Desulfurization of chalcopyrite with hydrogen was found to be most effective as compared to thermal decomposition under reduced pressure or in an inert gas stream. The reaction proceeds as shown below:

$\mathrm{CuFeS}_{2} \rightarrow \beta$-chalcopyrite $\rightarrow$ bornite $+\mathrm{Fe}_{1-\mathrm{x}} \mathrm{S} \rightarrow \mathrm{Fe}+$ bornite $\rightarrow \mathrm{Fe}+\mathrm{Cu}$.

Coagulation of the dissociated FeS into a massive particles and formation of bornite phase surrounding it were observed under a light microscope. Also, it was found that partially reduced product was leached readily by hydrochloric acid solution with a vigorous evolution of $\mathrm{H}_{2} \mathrm{~S}$ and $\mathrm{Cu}_{2} \mathrm{~S}$ was formed. The residue with 73 to 79 per cent copper was obtained under optimum conditions. The dissolution of iron in bornite was affected significantly by nonstoichiometry of bornite and was slightly influenced on the acid concentration or leaching temperature.

\section{明治初期のるつぼ (2)}

美濃錫産地として著名な恵那郡木積沢で は, 三井組も関与して明治 20 年代砂錫が製 鍊されていたが，現地には英国モルガン製 60番の黒鉛るつぼが保存されている。底に はMORGAN'S PATENT はじめ会社名, 番数が刻まれている。

( 葉賀七三男)

(林 龍一氏所蔵)
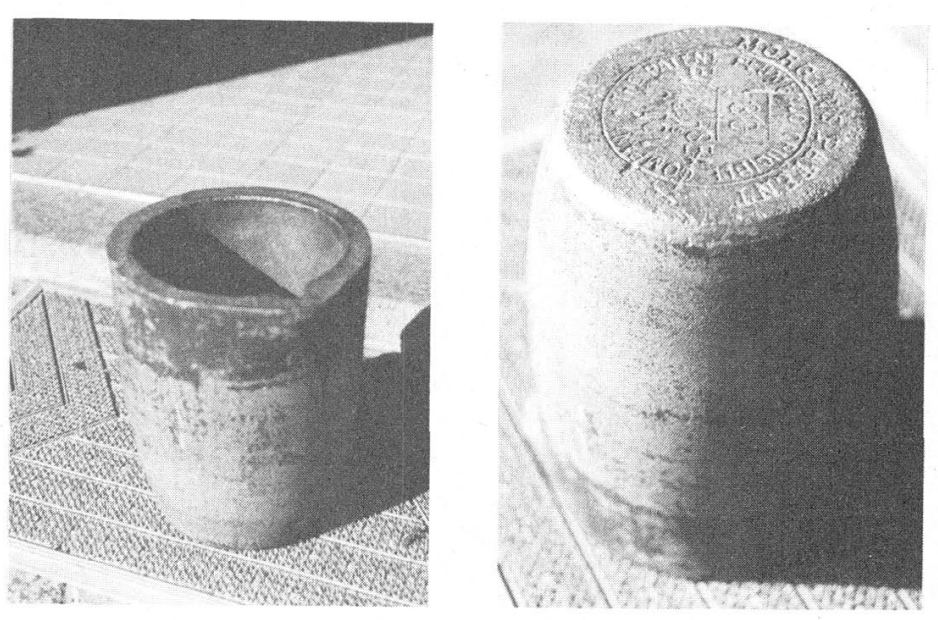